\title{
Dolomitization Mechanism Based on Petrography and Geochemistry in the Shotori Formation (Middle Triassic), Central Iran
}

\author{
A. Rahimi ${ }^{*}$, M. H. Adabi ${ }^{2}$, A. Aghanabati ${ }^{1}$, M. R. Majidifard ${ }^{3}$, A. M. Jamali ${ }^{4}$ \\ ${ }^{1}$ Department of Geology, Faculty of Sciences, Islamic Azad University, North Tehran Branch, Tehran, Iran \\ ${ }^{2}$ Department of Geology, Faculty of Geology, Shahid Beheshti University, Tehran, Iran \\ ${ }^{3}$ Research Institute for Earth Sciences, Geological Survey of Iran, Tehran, Iran \\ ${ }^{4}$ Surface Geology Exploration Section Directorate, National Iranian Oil Company, Tehran, Iran \\ Email: *rahimiazadeh19@gmail.com
}

How to cite this paper: Rahimi, A., Adabi, M.H., Aghanabati, A., Majidifard, M.R. and Jamali, A.M. (2016) Dolomitization Mechanism Based on Petrography and Geochemistry in the Shotori Formation (Middle Triassic), Central Iran. Open Journal of Geology, 6, 1149-1168.

http://dx.doi.org/10.4236/ojg.2016.69085

Received: July 18, 2016

Accepted: September 23, 2016

Published: September 26, 2016

Copyright $\odot 2016$ by authors and Scientific Research Publishing Inc. This work is licensed under the Creative Commons Attribution International License (CC BY 4.0).

http://creativecommons.org/licenses/by/4.0/

\begin{abstract}
Middle Triassic carbonate sequences of Shotori Formation have a thickness of $70 \mathrm{~m}$ and are deposited Robat-e-Kalmard region of Tabas city in Central Iran basin. Gradationally and conformably overlying Sorkh shale Formation, Shotori Formation, mostly composed of medium to thick dolomites $(50 \mathrm{~m})$, interbeded with thin lime and sandstones, is disconformable by a laterite horizon at its upper boundary. This Formation mainly consists of fine-to-coarsely crystalline dolomites. According to petrographic (fabric and grain size) and geochemical (elemental analysis of $\mathrm{Ca}, \mathrm{Mg}$, $\mathrm{Na}, \mathrm{Sr}, \mathrm{Fe}, \mathrm{Mn}$ ) evidence, five various types of dolomites were recognized in Shotori Formation. This variety results from early and late diagenetic processes, triggering a change in dolomitizing fluids and thereby forming various dolomites. Geochemical studies have revealed that the dolomites of Shotori Formation have formed under meteoric diagenesis and reducing conditions. Various dolomitization mechanisms are proposed for various types of dolomites; that is to say, Sabkha model is considered for type 1 dolomite, mixing zone model for type 2 and 3 dolomites and burial model for type 4 and 5 dolomites.
\end{abstract}

\section{Keywords}

Dolomitization, Petrography, Geochemistry, Shotori Formation, Central Iran

\section{Introduction}

Shotori Formation, with age of Middle Triassic (Anisian-Ladinian), is a thick-bedded 
carbonate sequence and the youngest Formation of Tabas group, located in central Iran basin. Dolomitization is a common alteration process in most limestones. Dolomite, coming in different types and shapes, is the major component of Shotori Formation. It can be found either in early or late forms, according to which the late dolomite forms immediately or short after deposition. The early dolomite, on the other hand, is directly supplied with seawater. This study employs a combination of petrographic and geochemical methods like main and trace elements to describe the dolomitic texture of Shotori Formation, their types and diagenesis process. This can assist in the determination of the origin of dolomites [1]-[8].

\section{Methodology}

A microscopic investigation was carried out on a sample of 90 thin sections to undertake stratigraphic studies and determine the facies of Chaharcheshmeh section. Employing Dickson's method [9], this study makes use of Alizarin Red Solution to stain thin sections, thereby differentiating calcites from dolomites. Two of the widely used methods of classification, namely Dunham [10] and Folk [11] were used to classify carbonate rocks. Dolomites, on the other hand, are classified based on a combination of textural classification, Sibley and Gregg [1] and Mazzullo [4]. To measure the size of dolomites, the classic model of Folk [12] [13] and much more recent model of Adabi [7] [8] are used. The variety of dolomites accounts for their Formation time, source and early limestone composition. To conduct the geochemical and elemental studies, samples of 14 dolomite rocks were selected. Samples were collected from micritic matrix, where no veins, alteration and allochems exist, and then powdered using a crusher and dental drills. The powdered samples were sent to Applied Geological Research Center of Iran to determine the main and trace elements using ICPOES. Due to its accuracy and capability to read detection limits at extremely low levels, this analytical technique is widely used to analyze various main and trace elements expressed in ppm and percentage.

\section{Stratigraphy of Shotori Formation in the Studied Area}

Chaharcheshmeh stratigraphic section in southeastern Kalmard block with geographical coordinates of $56^{\circ} 12^{\prime} \mathrm{E}$ and $33^{\circ} 23^{\prime} \mathrm{N}$ is $100 \mathrm{~km}$ away from road Tabas-Yazd (Figure 1). Shotori Formation shows a thickness of $70 \mathrm{~m}$, and is composed mostly of dolomite, interbeded with limestone and a little sandstone. The lower boundary, covered by shale, siltstone and sandstone, gradually changes into dolomitic carbonates of tidalflat sub environment (Figure 2 \& Figure 3). Thick-to-massive layered sequences of dolomitic rocks of Shotori Formation are gradationally overlain by a thin-to-thick layered limestone belonging to Espahak lime. In the studied area, the upper boundary of Shotori Formation has been covered by a laterite horizon (Figure 4). Medium-to-thick dolomites, interbeded with shallow marine thin limestone have been deposited in Mid-Triassic carbonate platform of Shotori Formation. 


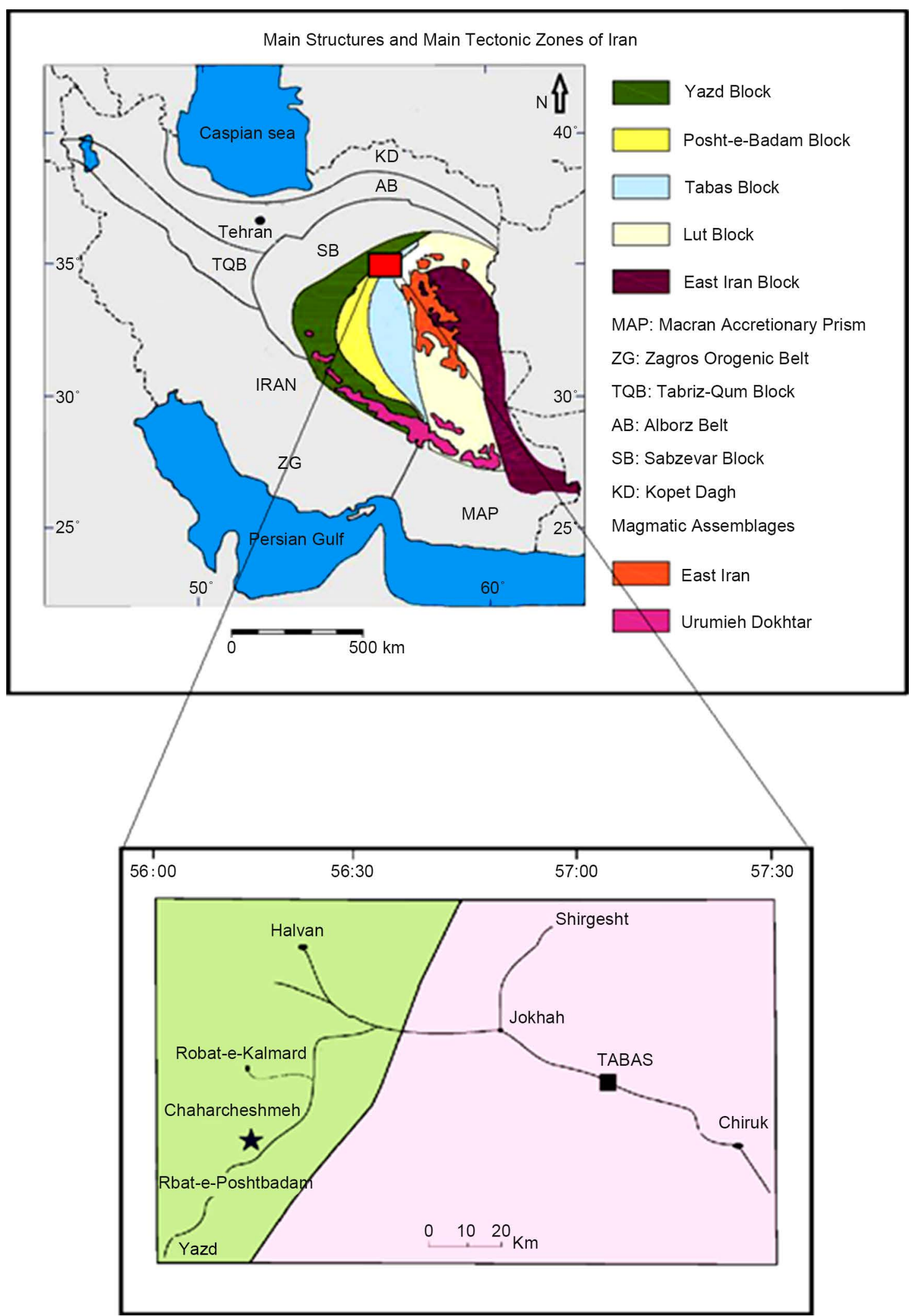

Figure 1. Major structural-depositional zones of Iran (Stöcklin \& Nabavi, 1968) (reload by Nezafati, 2006) and geographical setting of the studied area. 


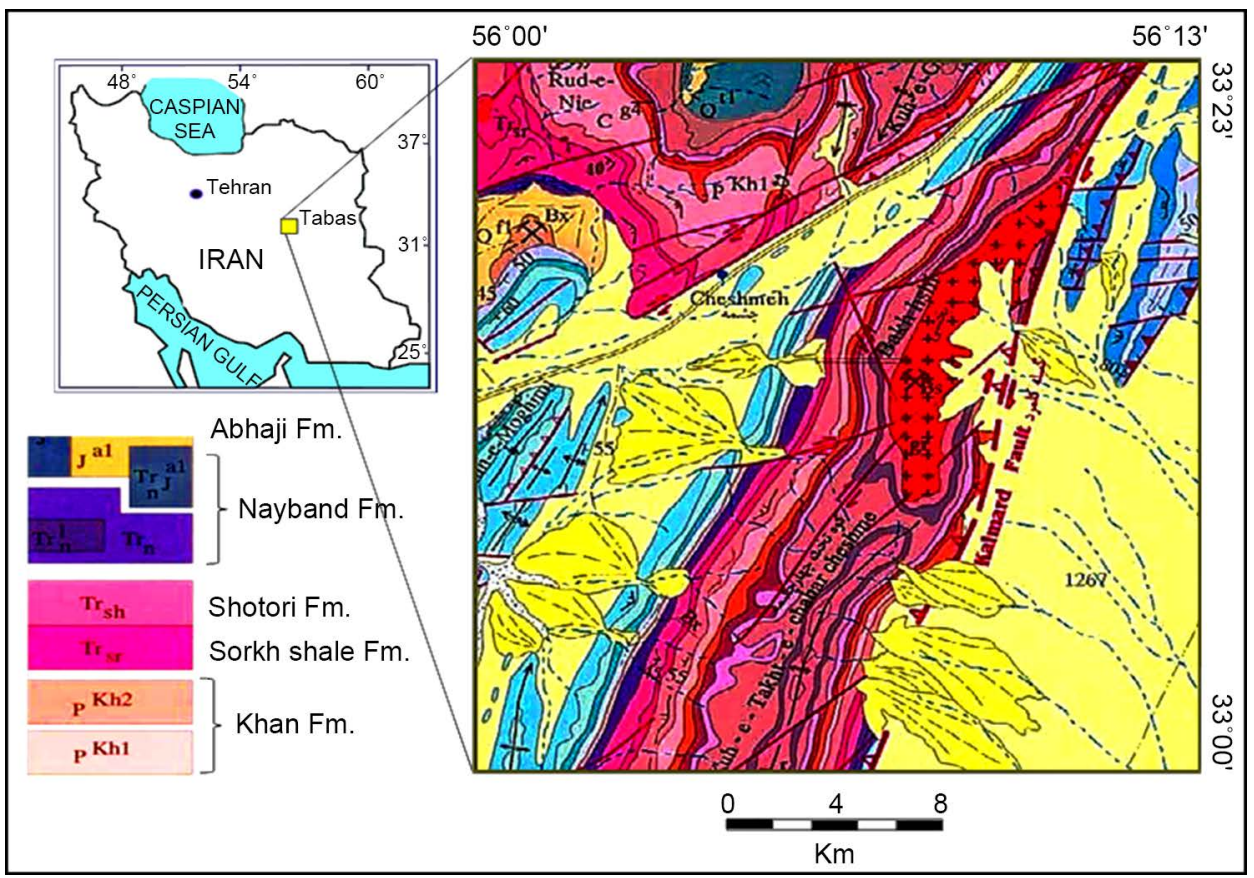

Figure 2. Chaharcheshmeh Stratigraphic section on the geological map Robat khan $(1: 100,000)$, (adopted from GSI, 2000).

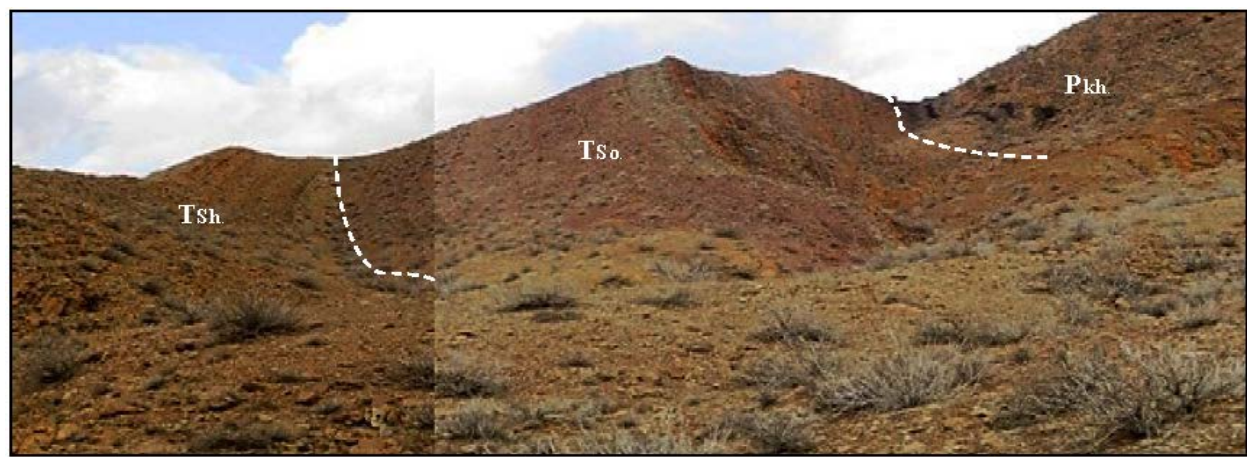

Figure 3. The sequence of upper Permian (Pkh), lower and middle Triassic deposits of Sorkh shale (TSo.) and Shotori (TSh.) in Chaharcheshmeh stratigraphic section (north western ward).

\section{Dolomites Petrography}

Dolomites, coming in various shapes and types, are very important parts of Shotori Formation. The dolomites of Shotori Formation are divided into five types based on their fabric types and 1) whether the crystal size distributions are unimodal or polymodal, and 2) whether their crystal boundary shapes are planar and nonplanar. Crystal size distribution is controlled by nucleation and growth kinetics, and crystal boundary shape is controlled by growth kinetics [1]. In the case of low temperature, the crystals will be subhedral to anheral and referred to as planars. However, at critical roughening temperature, estimated to lie between 50 to $100 \mathrm{C}$, nonplanar and anhedral crystals are developed [14] [15]. In this study, the dolomite crystals size is determined by measuring crystal diameter and based on Adabi [7] [8]. 


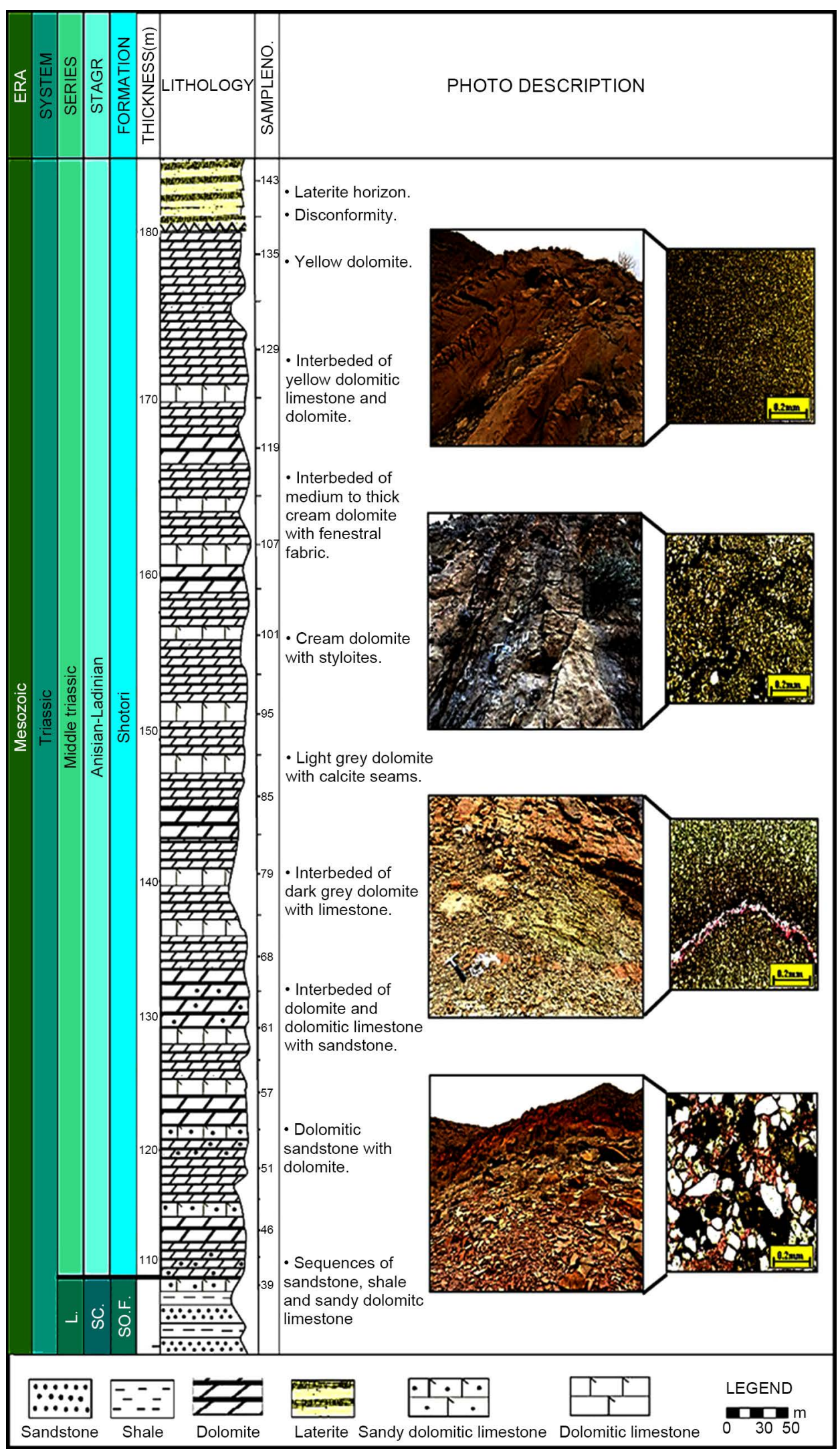

Figure 4. Stratigraphy column of the studied area. 


\section{Dolomites Types}

\subsection{Dolomicrite (Very Fine to Finely Crystalline Dolomite)}

This type of dolomite, varying from 4 to 16 micron in size (average: 4 micron), is characterized as planar-s crystal subhedral and unimodal mosaic in shape. This is equivalent to Xenotopic [16], Nonplanar-A [4] and Xenotopic-A [14]. These dolomites are mostly concentrated and lack porosity and fossil (Figure, 5-A). Dolomicrites are more frequent at low temperature and under surface conditions in upper tidalflat to tidalflat environments, and are characterized by their fabric type, microcrystals, early depositional texture and lack of fossil [7] [14] [15]. According to Land [17], seawater and Mg-enriched pore water account for this dolomitization process. Geochemically speaking, these dolomites contain higher $\mathrm{Sr}$ and $\mathrm{Na}$ yet less Fe and Mn than secondary dolomites [7] [18].

\subsection{Dolomicrosparite (Fine to Medium Crystalline Dolomite)}

These dolomites, ranging from 16 to 62 micron in size (average: 36 micron), are composed of planar-s (subhedral to anhedral) crystals and look like unimodal mosaics. They enjoy straight inter crystalline boundaries, and crystalline surfaces have been well preserved in some cases (Figure 5(b)). This dolomite is equal to idiotopic [16], idiotopic-p [14] and planar-p [4]. Planar-s fabric develops when crystals undergo slow growth at a low temperature and under a continuous trend of dolomitizing fluids [1]. We interpret type 2 dolomites to be the product of the late diagenetic replacement of limestones or recrystallization of early dolomites under critical roughening temperature (below $60^{\circ} \mathrm{C}$ ) [4] [7] [15].

\subsection{Dolosparite (Medium Crystalline Dolomite)}

These dolomites, varying from 62 to 250 micron in size (average: 135 micron), are concentrated and characterized as planar-s to nonplanar-a and unimodal mosaics. The fabric of these dolomites is equal to hypidiotopic [16], idiotopic-s [14] and planar-s dolomites [1] [4]. Dolosparites are likely to be the product of recrystallization of types 1 and 2 dolomites. These dolosparites are responsible for destruction of early depositional texture (Figure 5(c) and Figure 5(d)). Some of these dolomites have cloudy core and clear rim. According to Sibley [19], these dolomites develop when dolomitizing solutions are saturated with respect to calcite, while, as reaction progresses, the chemical composition of these dolomitizing solutions are under saturated with respect to calcite, thereby creating a clear rim lacking inclusion.

\subsection{Vein Dolomite (Coarsely Crystalline Dolomite)}

Vein dolomites are composed of coarsely crystals, ranging from 200 to 1100 micron in size (average: 600 micron). These dolomites contain anhedral, nonplanar and poly modal crystals. Crystals of vein dolomites exhibit a clear boundary with fracture wall and, in most cases, show an undulatory extinction similar to that of saddle dolomites, 

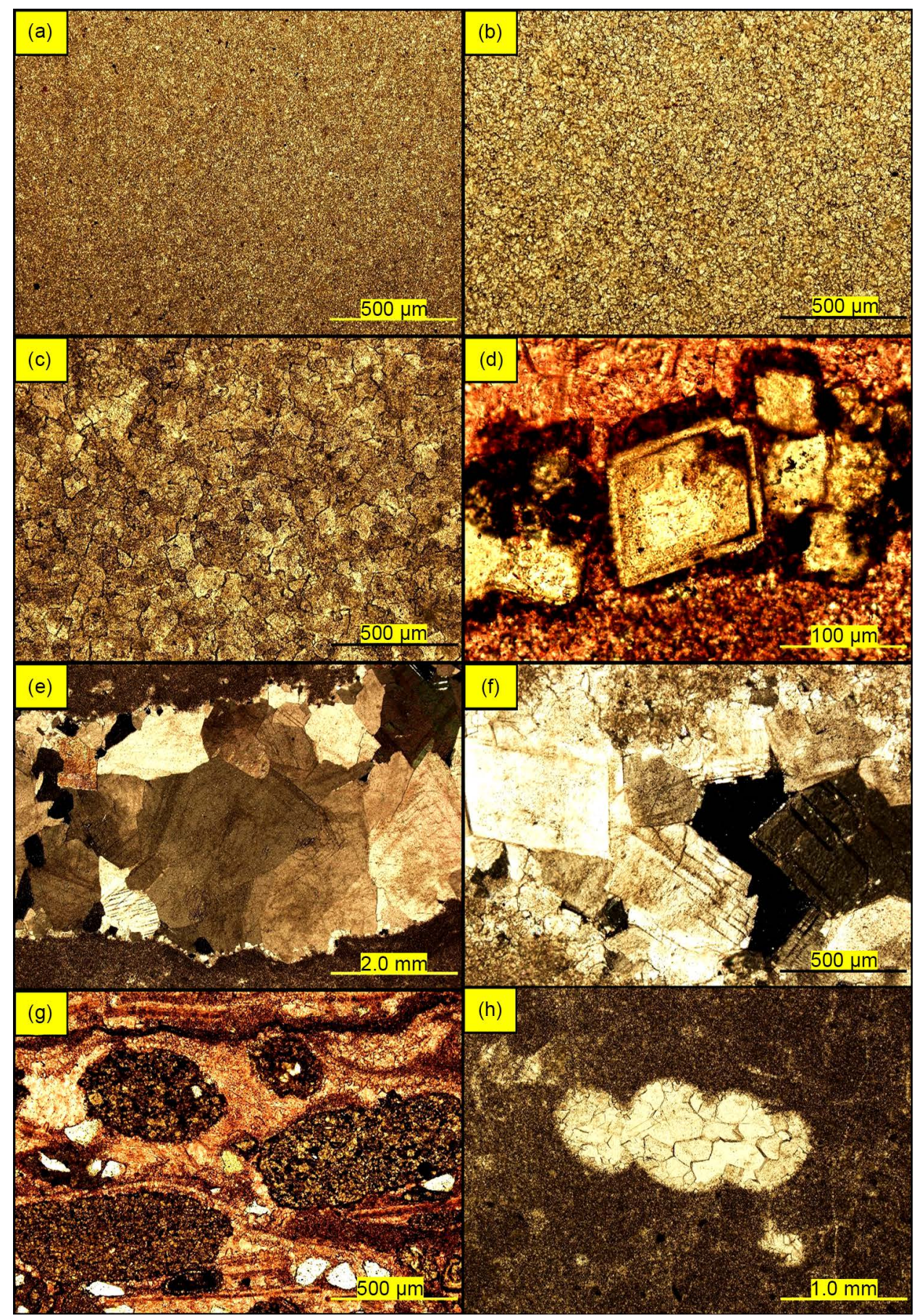

Figure 5. (a) Dolomicrite. Type 1 dolomicrite, very fine crystalline, anhedral, Xenotopic (XPL); (b) Dolomicrosparite, Type 2 dolomite, fine to medium crystalline, anhedral to subhedral, Hypidiotopic (XPL); (c) Dolosparite, type 3 dolomite, medium crystalline, subhedral to euhedral. Hypidiotopic to idiotopic, clear rim and cloudy core (XPL); (d) Sucrosic dolomites, rhombohedral, euhedral, idiotopic, in a calcite matrix stained with red alizarin solution (ordinary light); (e) pore-filling dolomite, type 4 dolomite, coarsely crystalline, anhedral (PPL); (f) Saddle dolomite, type 5 dolomite, coarsely crystalline, undulatory extinction (PPL); (g) Selective dolomitization, complete dolomitization of intraclast (ordinary light); (h) Complete dolomitization of gastropod due to early aragonite mineralogy dissolution and its replacement with dolomite (XPL). 
pointing to its Formation at a temperature of above $100^{\circ} \mathrm{C}$. In some cases, pore-and vein-filling dolomites contain little Fe (Figure 5(e)). Vein dolomites usually cut dolomicrites (early dolomites), dolomicrosparites (early diagenetic dolomites) and dolosparites (late diagenetic dolomites) and hence is interpreted as the final product of dolomitization.

\subsection{Saddle Dolomites}

Saddle dolomite often occurs in sulfate-bearing carbonate host rocks associated with hydrocarbons and epigenetic sulfides [20]. These dolomites are commonly formed under burial or hypothermal conditions from high-saline brines and under high temperature, as a by-product of thermo chemical sulfate reduction [21]. They contain coarse crystal dolomites, generally a millimeter or larger in size. They also have calcite inclusion and some anhydrite as well as curved saddle-like crystal faces and undulatory extinction [20] [22]. In Shotori Formation, these dolomites have mostly occupied the moldic and vuggy porosities and exhibit nonplanar surface followed by undulatory extinction. This implies the Formation of these dolomites at a temperature higher than $100^{\circ} \mathrm{C}$ [22] or higher than $60^{\circ} \mathrm{C}$ [15]. Saddle dolomites are mostly found within fractures and pores, proving its late origin (Figure $5(\mathrm{e})$ ). The paragenetic sequences of the dolomites of Shotori Formation are presented in Figure 6.

\subsection{Selective Dolomitization}

Partial or selective dolomitization is a dominant process in some parts of the thin sections of Shotori Formation in section Chaharcheshmeh. Dolomitization process has affected intraclasts and skeletal particles in some sections (Figure 5(h) \& Figure 5(g)) while it has occurred in micritic matrix. Such a dolomitization is believed to be associated with and follow rock's fabric. Selective dolomitization is likely to be associated with original aragonite mineralogy or fine-grained allochems. Aragonite and micritic allochems are highly susceptible to dolomitization [8] [23] [24]. If a sequence is partially dolomitized and the remaining $\mathrm{CaCo} 3$ is not dissolved, porosity will not spread

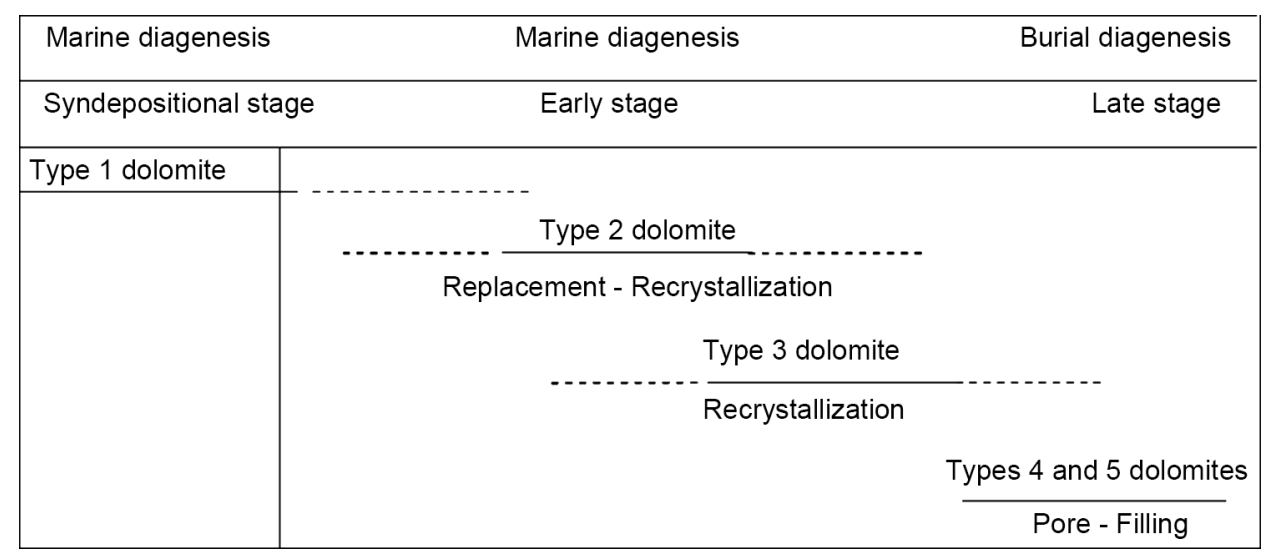

Figure 6. Paragenetic sequence of different dolomites in Shotori Formation, continuous lines indicate relative period of dolomitization while dotted lines show probable time of occurrence. 
[25] [26]. All in all, if a mud sequence is selectively dolomitized by a fabric, a dolomitic mosaic with interlocking crystals form, thereby reducing or removing porosity [27]. Also, the burial dolomitization of grainstones or other porous facies can preserve and spread porosity under burial conditions. Selective dolomitization together with $\mathrm{CaCO}_{3}$ dissolution can remarkably trigger good reservoir properties [23] [26].

\section{Geochemical Studies}

One of the major steps to take is to determine the values of the main and trace elements. Investigating these studies can provide fruitful information on dolomites origin (early or late), formation time, dolomitizing fluid composition, and dolomitization model and diagenesis process. Many scholars [1] [4] [7] [24] [28]-[34] have deeply examined dolomites and dolomitization mechanisms.

\subsection{Main and Trace Elements in Dolomites}

Identifying diagenetic processes in dolomites is tied with dolomitizing fluids [35]-[37]. Identification of the elements like calcium, magnesium, sodium, strontium, manganese and iron in dolomites can lead to the detection of dolomitizing fluids. The concentration of the main and trace elements in various dolomites of Shotori Formation is presented in Table 1.

Table 1. The variety of main and trace elements in the dolomites of Shotori Formation in the studied area.

\begin{tabular}{|c|c|c|c|c|c|c|}
\hline \multicolumn{7}{|c|}{ Dolomitic Samples } \\
\hline Sample. No & $\operatorname{Mg}(\%)$ & $\mathrm{Ca}(\%)$ & $\mathrm{Na}(\mathrm{ppm})$ & $\mathrm{Sr}(\mathrm{ppm})$ & $\mathrm{Fe}(\mathrm{ppm})$ & $\mathrm{Mn}(\mathrm{ppm})$ \\
\hline 1 & 5.76 & 29 & 286 & 1272 & 1000 & 141 \\
\hline 2 & 7.14 & 20.16 & 261 & 925 & 4900 & 159 \\
\hline 3 & 6.38 & 28.1 & 243 & 627 & 9000 & 179 \\
\hline 4 & 8.35 & 21 & 216 & 263 & 9400 & 194 \\
\hline 5 & 7.43 & 29.3 & 185 & 208 & 11,700 & 267 \\
\hline 6 & 9.62 & 27.6 & 163 & 124 & 12,300 & 289 \\
\hline 7 & 8.35 & 20.7 & 137 & 151 & 13,500 & 316 \\
\hline 8 & 10.2 & 22.63 & 131 & 137 & 18,600 & 371 \\
\hline 9 & 8.6 & 24.9 & 125 & 168 & 25,300 & 386 \\
\hline 10 & 9.82 & 26.5 & 121 & 102 & 25,600 & 439 \\
\hline 11 & 10.77 & 21.32 & 104 & 108 & 27,300 & 652 \\
\hline 12 & 12.8 & 26.5 & 107 & 130 & 27,300 & 1070 \\
\hline 13 & 11.46 & 28.95 & 106 & 100 & 42,200 & 1244 \\
\hline 14 & 11.3 & 25.72 & 100 & 85.5 & 66,000 & 1955 \\
\hline
\end{tabular}




\subsubsection{Main Elements}

\section{Calcium and Magnesium}

The Ca content in the dolomites of Shotori Formation varies from $20.7 \%$ to $29.3 \%$ (average: 24.9). The amount of $\mathrm{Mg}$ in these dolomites is in the range of 5.76\% to $12.8 \%$ (average: 9.62). The reduction in the $\mathrm{Mg}$ value in fine crystalline type 1 dolomites is due to their Ca content. As can be seen in Figure 7, the amount of $\mathrm{Mg}$ in these dolomites is positively associated with $\mathrm{Mg} / \mathrm{Ca}$ ratio $\left(\mathrm{R}^{2}=0.98\right)$. Since $\mathrm{Mg} / \mathrm{Ca}$ ratio in pure dolomites equals $65 \%$, a drop in $\mathrm{Mg}$ content from $12.8 \%$ to $5.76 \%$ is the result of their alteration. The maximum amount of $\mathrm{Mg}$ in pure dolomites is $13 \%$. The $\mathrm{Ca}$ versus $\mathrm{Mg}$ variations results from replacing amount of $\mathrm{Ca}$ with $\mathrm{Mg}$ in dolomitic carbonates (Figure 8).

\subsubsection{Trace Elements}

\section{1) Strontium}

Among the trace elements involved in dolomites, $\mathrm{Sr}$ has always attracted a lot of attention [17] [35] [38]. Sr concentration depends on many factors. Since Sr is replaced with $\mathrm{Ca}$, and $\mathrm{Ca}$ content in dolomites is half the amount of $\mathrm{Ca}$ in calcite, $\mathrm{Sr}$ in dolomites does not show as much concentration as in limestone [37]. Land [31] believed that primary dolomites contain higher $\mathrm{Sr}$ than secondary (diagenetic) dolomites, which is due to the change in their fabric. Sr concentration increases with reducing size of crystals, and hence diagenetic dolomites, which involve more coarse crystals than primary dolomites, contains less Sr content [34]. On the other hand, the Sr value of the primary mineral replaced with dolomite is also of great importance [39]. Generally, dolomites replaced with aragonite contain higher Sr than those replaced with calcite. Humphrey [36] discussed that the high content of Sr in dolomites accounts for dolomitization of aragonite limes in semi-closed diagenetic environments. The Sr value of

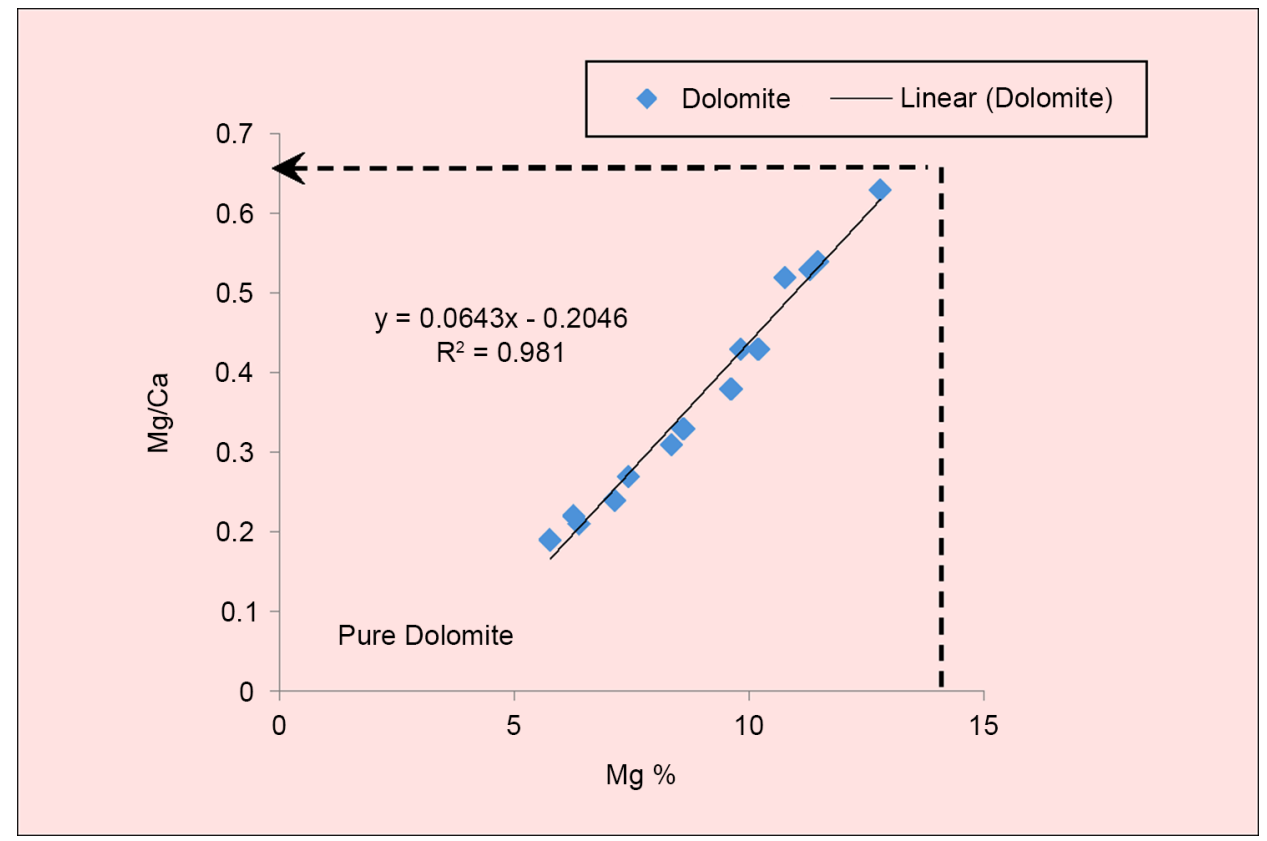

Figure 7. $\mathrm{Mg} / \mathrm{Ca}$ to $\mathrm{Mg}$ ratio variations in the dolomites of Shotori Formation. 


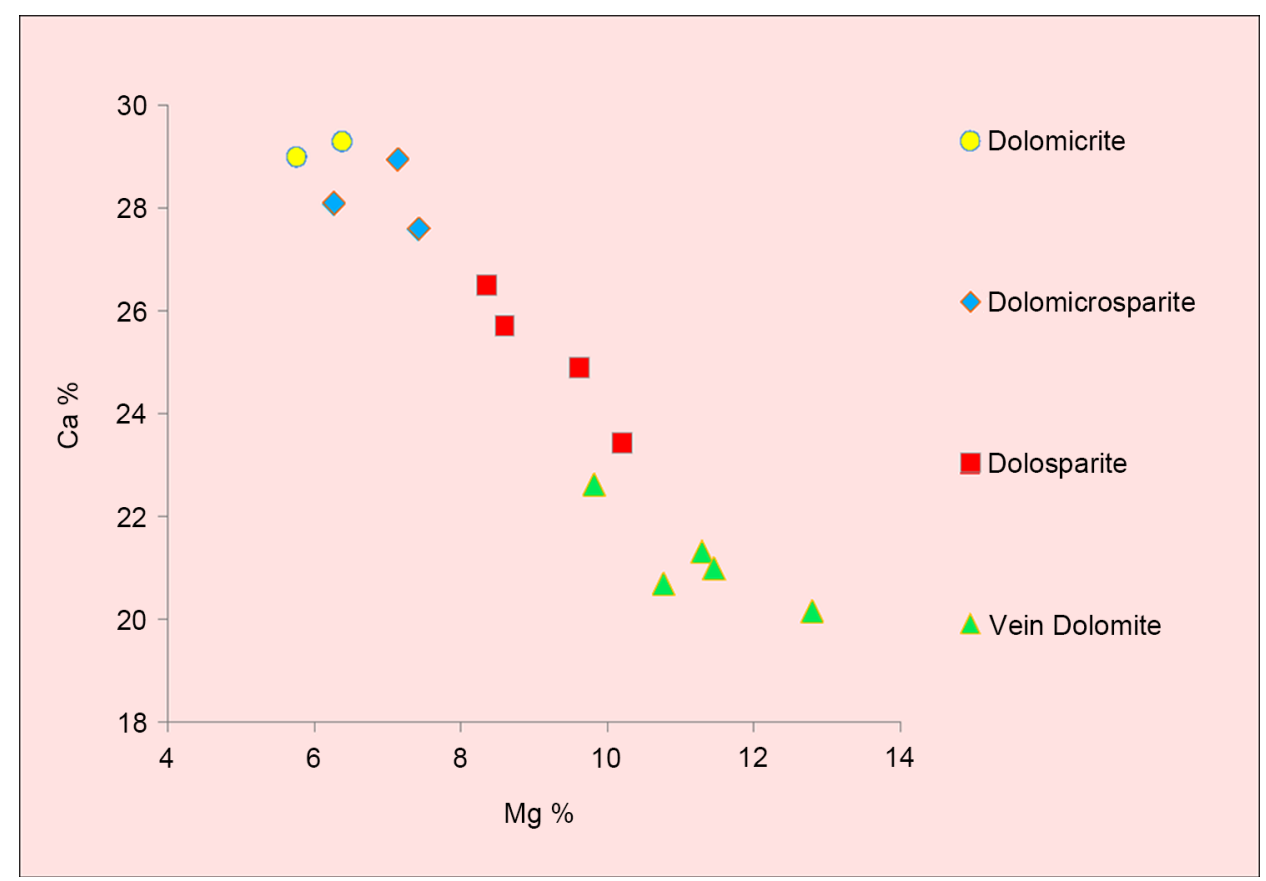

Figure 8. Mg versus $\mathrm{Ca}$ values plot for the dolomites of Shotori Formation. As depicted, $\mathrm{Mg}$ content decreases more in type 1 , fine crystal dolomites than any other types of dolomites due to their high Ca content.

dolomites in Shotori Formation varies from 85.5 to $1000 \mathrm{ppm}$ (average: $263 \mathrm{ppm}$ ) (Figure 9). The amount of $\mathrm{Sr}$ in dolomites is less than limes, which is due to the smaller distribution coefficient of $\mathrm{Sr}$ in dolomites [35]. Sr concentration in type 1 dolomites is relatively higher than other dolomites. $\mathrm{Sr}$ versus $\mathrm{Mg}$ diagram in various dolomites indicates an increasing trend so that Sr content increases with increasing Mg (Figure 9), due to the non-stoichiometric characteristic of dolomites (irregular crystals lattice). Strontium content of dolomites increases as their Stoichiometry characteristic decreases [40]. Accordingly, stoichiometric dolomites (containing 50 mole $\% \mathrm{MgCO}_{3}$ ) contain 50 ppm Sr while dolomites with 40 mole $\% \mathrm{MgCO}_{3}$ contain $253 \mathrm{ppm} \mathrm{Sr}$ [8] [24]. The higher amount of $\mathrm{Sr}$ in the dolomites of Shotori Formation than the average amount of this element in stoichiometric dolomites $(50 \mathrm{ppm})$ is probably due to the non-stoichiometric dolomites of Shotori Formation or aragonite limes replacement.

\section{2) Sodium}

Sodium is the most abundant cation in seawater and recognized as a paleosalinity indicator in ancient fluids [41] [42]. Na is closely concentrated in most dolomites. This $\mathrm{Na}$ value, typically ranging from 110 to $160 \mathrm{ppm}$, is higher than that of the average dolomites formed in a normal-saline marine environment [35]. $\mathrm{Na}$ versus $\mathrm{Mg}$ diagram reveals that $\mathrm{Na}$ concentration increases with increasing $\mathrm{Mg}$ (Figure 10). Na content, like that of $\mathrm{Sr}$, is very low in stoichiometric dolomites and thus high amount of $\mathrm{Mg}$ in dolomites accounts for their non-stoichiometry (irregularity of dolomite lattice, in other words, lattice defect), resulting from hyper salinity of dolomitizing fluids. Sodium is frequently used to measure the ancient paleosalinity [17] [35] [42]. It is noteworthy that 


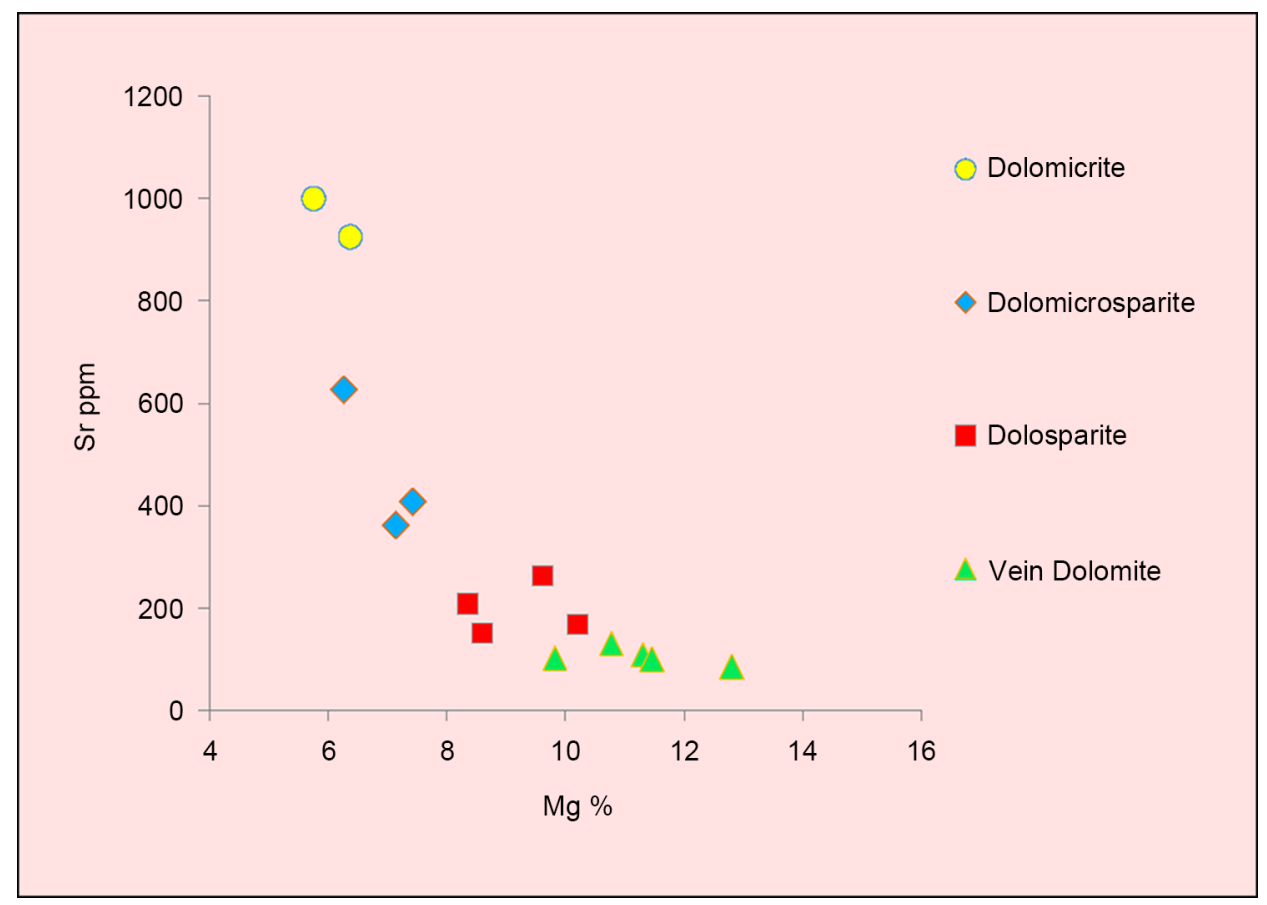

Figure 9. Mg versus Sr variations in the dolomites of Shotori Formation. The high amounts of $\mathrm{Sr}$ in the studied dolomites are likely as a result of the early aragonite mineralogy of the dolomitized limes. As can be seen, Sr value in dolomicrite is higher than any other types of dolomites since they are not significantly influenced by non-marine diagenesis.

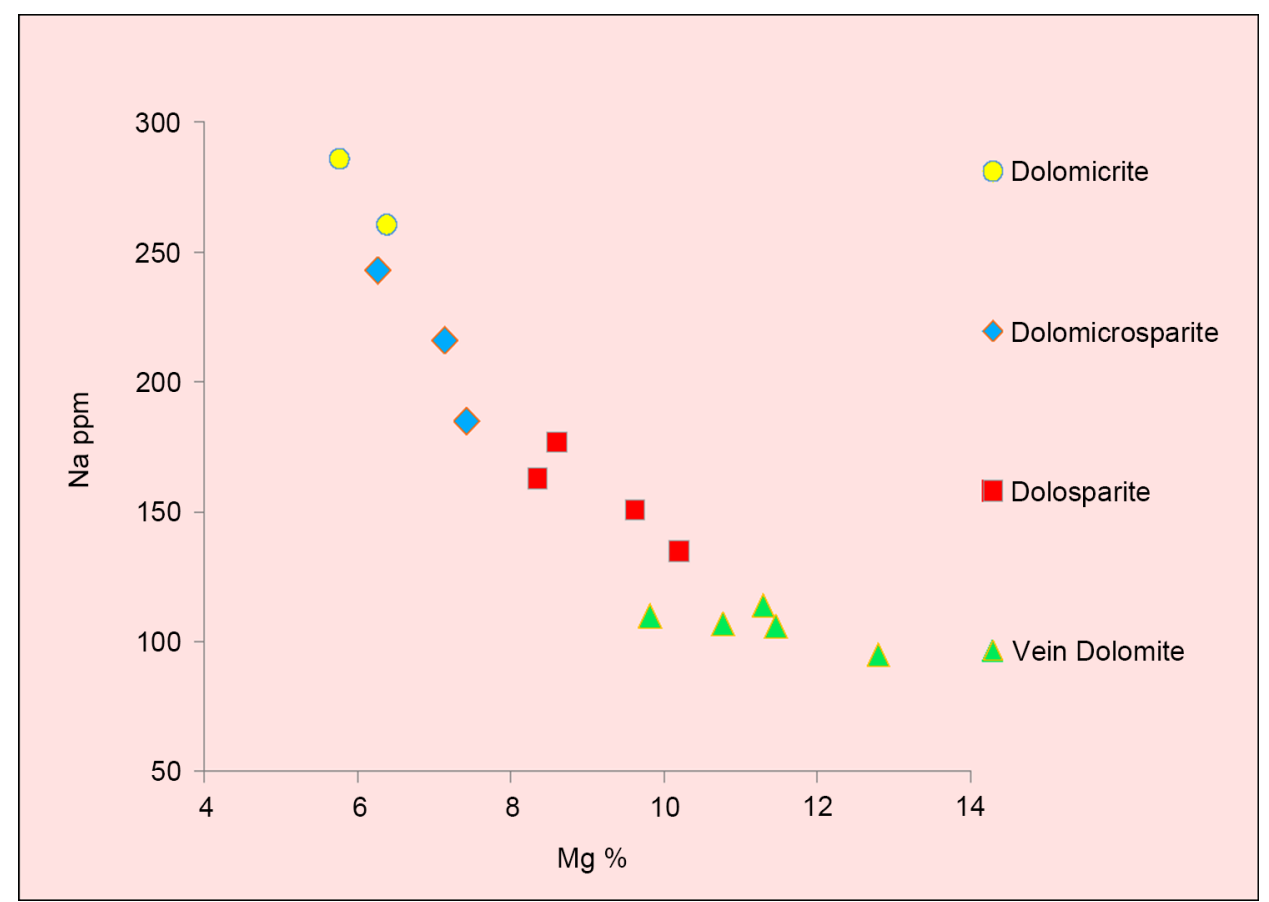

Figure 10. $\mathrm{Na}$ versus $\mathrm{Mg}$ variations in various dolomites of Shotori Formation. Notice that the increasing trend of $\mathrm{Mg}$ against $\mathrm{Na}$ indicates the non-stoichiometric state of the dolomites in Shotori Formation. High $\mathrm{Na}$ content seems to be due to the salinity of dolomitizing fluids or partial effect of non-marine diagenesis on the studied samples. 
dolosparites contain less sodium than dolomicrites. This trend is caused by greater effects of diagenesis on coarse-grained dolomites.

\section{3) Iron and Manganese}

Unlike strontium and sodium, the amount of $\mathrm{Fe}$ and $\mathrm{Mn}$ in late diagenetic dolomites is higher than that of early dolomites. This can be due to the following reasons:

- Fe and Mn are less concentrated in seawater than in diagenetic fluids.

- Higher concentration of $\mathrm{Fe}$ and $\mathrm{Mn}$ depends on the reducing conditions dominating the environment so that the amounts of Fe and $\mathrm{Mn}$ in primary dolomites near surface, due to the oxidizing conditions, are less than those of burial dolomites formed in reducing conditions [43].

$\mathrm{Mn}$ and Fe concentration in the dolomites of Shotori Formation varies from 119 to 1955 (average: $371 \mathrm{ppm}$ ) and from 1000 to 45,000 (average: $1860 \mathrm{ppm}$ ), respectively. The average amounts of $\mathrm{Mn}$ and $\mathrm{Fe}$ in the studied dolomites are much higher than in limes since $\mathrm{Mn}$ and Fe usually substitute $\mathrm{Mg}$. The higher content of $\mathrm{Mg}$ in dolomites than in limes causes a rise in the concentration of these elements in dolomites as well. Due to the higher distribution coefficient of $\mathrm{Mn}$ and Fe in calcite and dolomite [35] [44], the higher concentration of these elements in the dolomites of Shotori Formation points to the reducing conditions dominating the environment [45]. Reducing conditions go up with a further increase in burial depth. Those late diagenetic dolomites occurring under reducing conditions (type 3 and 4) show more $\mathrm{Mg}$ and Fe than early; near-surface dolomites (type 1 and 2). As a result of low concentration of $\mathrm{Mn}$ and Fe in marine fluids, a rise in the $\mathrm{Mn}$ and Fe content of fine-crystal dolomites (minimum alteration) to coarse-crystal dolomites (maximum alteration) results from their non-marine inclusion [18]. Mn-Fe versus $\mathrm{Mg}$ variations is depicted in Figure 11. Therefore, the high content of $\mathrm{Mn}$ and $\mathrm{Fe}$ in the dolomites of Shotori Formation is influenced by the reducing conditions in which dolomites form. The higher effect of diagenesis, moreover, can enhance the average values of $\mathrm{Fe}$ and $\mathrm{Mn}$ in dolosparites. Mn versus $\mathrm{Fe}$ diagram indicates a linear trend with positive slope (Figure 12). This increasing trend is attributed to the alteration of dolomites by diagenetic fluids (non-marine).

\section{Dolomitization Mechanisms}

Three dolomitization mechanisms used in this study include Sabkha model, mixing zone model and burial model.

\subsection{Sabkha Model}

The roots of type 1 dolomites can be sought within Sabkha model. According to petrographic evidence like fine crystal texture and fenestral fabric, type 1 dolomites are recognized as very early diagenetic dolomites or syndepositional dolomites. These dolomites are accompanied by sequences showing the characteristics of Sabkha model with respect to lithofacies. Among this evidence, one can point to the supratidal facies, lamination, fenestral and evaporate crystals [20] [46]. Additionally, the presence of fine-crystal dolomites is an indicator of appropriate sites for nucleation of dolomite 


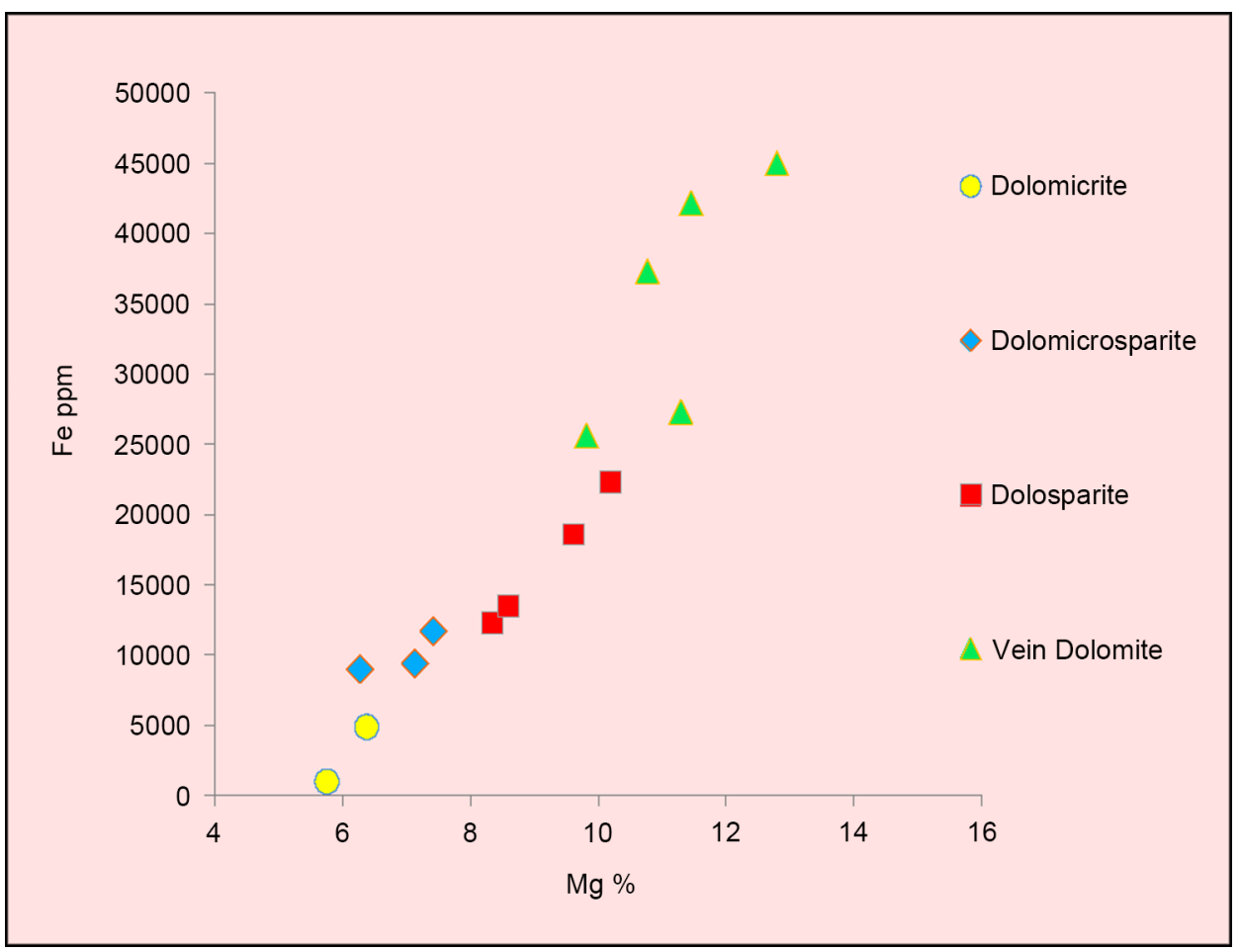

(a)

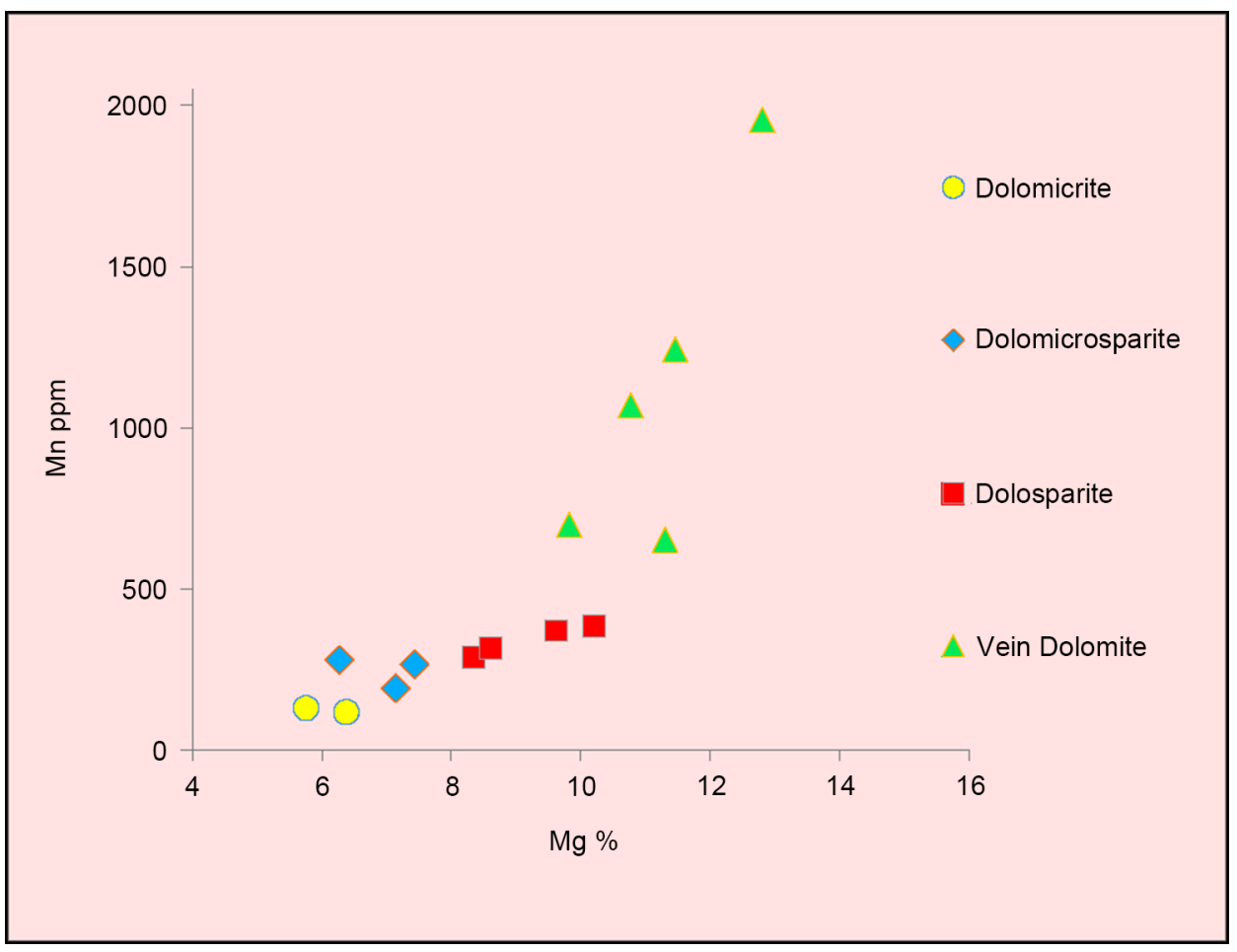

(b)

Figure 11. Fe and $\mathrm{Mn}$ versus $\mathrm{Mg}$ variations in the dolomites of Shotori Formation. Fe and $\mathrm{Mn}$ values increase with increasing $\mathrm{Mg}$ value, resulting from preferential replacement of $\mathrm{Fe}$ and $\mathrm{Mn}$ with $\mathrm{Mg}$ in dolomite crystal lattice. Regarding the higher impact of diagenesis on dolosparites, the average amount of $\mathrm{Fe}$ and $\mathrm{Mn}$ in these types of dolomites is higher than that of dolomicrites. 


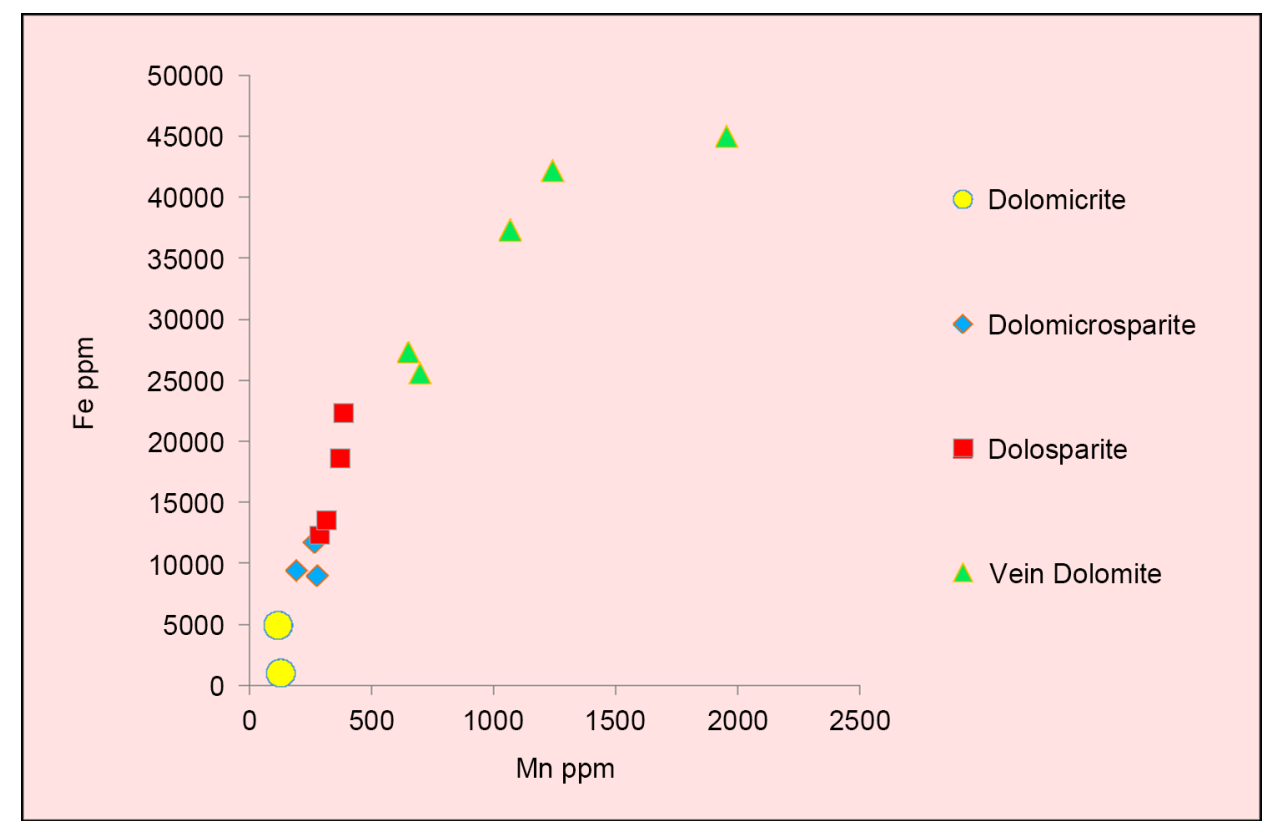

Figure 12. Mn versus Fe variations in various dolomites of Shotori Formation. As can be seen, these elements have a linear association with positive slope. Fe and $\mathrm{Mn}$ values rise with rising alteration caused by diagenetic fluids.

crystals in Sabkha fine-grained (micritic) sediments [1] (Figure 13(a)).

\subsection{Mixing Zone Model}

This model is attributed to Type 1 and Type 2 dolomites. In this model, dolomitizing fluids result from seawater-subsurface meteoric water mixture [47] [48], subsurface meteoric water saturated with $\mathrm{CO}_{2}$ is mixed with seawater and the resulting solution is under saturated with respect to $\mathrm{CaCO}_{3}$ and supersaturated with respect to dolomites [8] [23] [24]. According to the lithological structures, various dolomites including mold porosity and equant calcite (freshwater) cement are identified in mixing zone. The dolomitization model of dolomicrosparites and sucrosic dolomites are attributed to this model (Figure 13(b)).

\subsection{Burial Model}

Type 4 and type 5 dolomites develop based on burial model. Three major sources of the necessary $\mathrm{Mg}$ in burial dolomitization include bitten salts (polyhalite carnallite), magnesium emanating from the conversion of clay minerals and interstitial waters (including connate marine water and connate evaporate brines) [17]. Connate marine water seems to be the most important source of $\mathrm{Mg}$ required for dolomitization occurring in medium to deep burial periods [49]. Burial dolomites develop as replacement below the active phreatic zone in permeable intervals flushed by warm to hot magnesiumenriched basinal and hydrothermal waters that was subsequently covered and removed by late-stage dolomites [20]. Saddle and pore-filling dolomites as well as iron-enriched dolomites in Shotori Formation account for burial conditions (Figure 13(c)). 


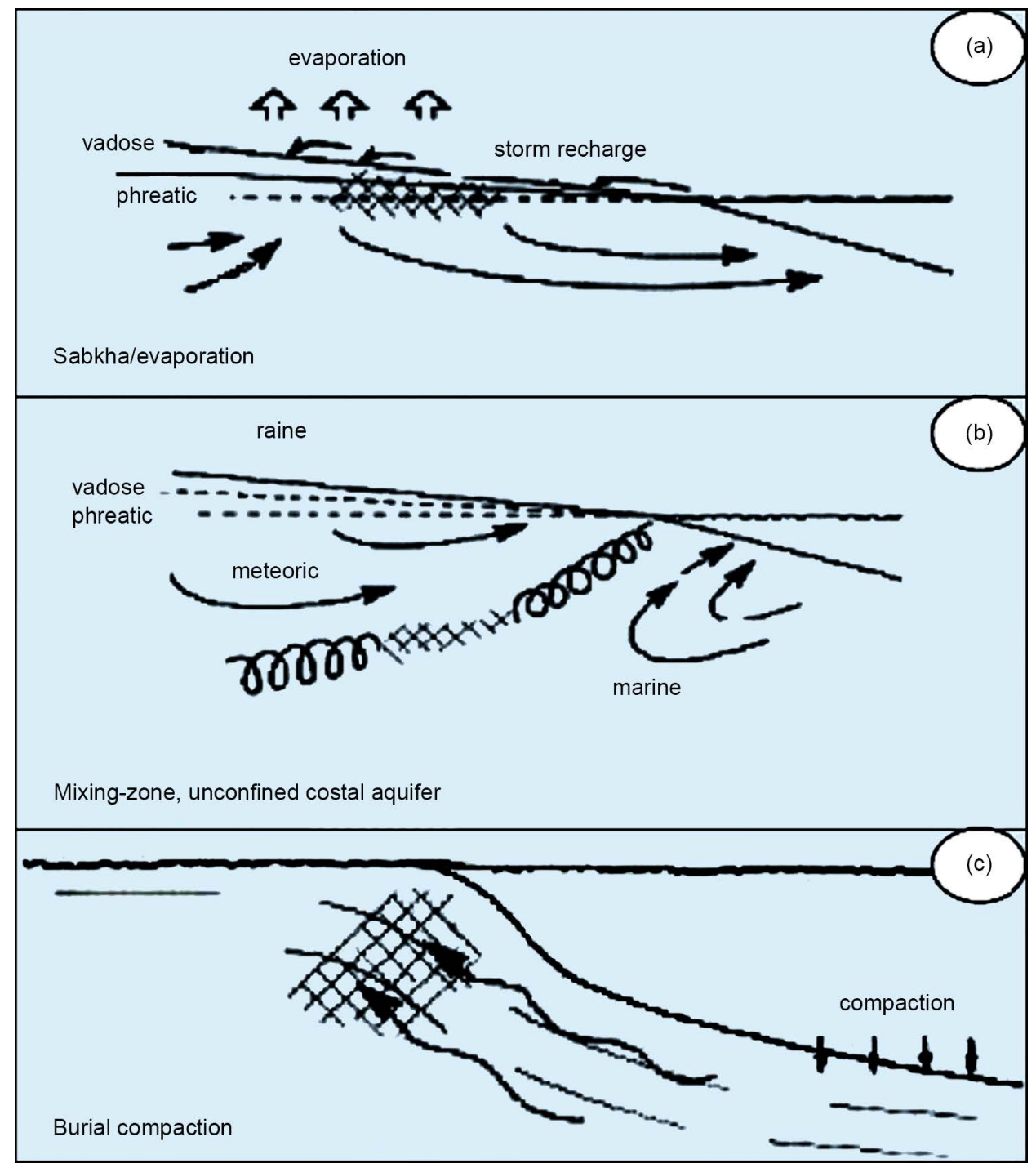

Figure 13. Dolomitization models in Shotori Formation (adopted from Tucker \& Wright, 1990 \& Warren, 2000).

\section{Mg Source}

Seawater is the only source of $\mathrm{Mg}$ capable of forming early dolomitization or syndepositional dolomitization [17]. This source is considered only for type 1 dolomites, formed near the surface and under low temperature in a tidal environment due to seawater influx into this area. The necessary $\mathrm{Mg}$ for types 2, 3, 4 and 5 dolomites can be sourced from various sources including connate marine waters or basinal brines [8] [23] [24].

\section{Conclusions}

- Shotori Formation is a middle Triassic carbonate sequence, which is mostly composed of medium-to-thick bedded dolomites, interbedded with thin limes and sandstones. This Formation conformably and gradationally overlies Sorkh shale Forma- 
tion and is cut by a fault at its upper boundary.

- Petrographic studies of the collected samples indicate that dolomite is one of the most important components of this Formation. Five various types of dolomites including dolomicrite, dolomicrosparite, dolosparite, vein dolomites and saddle dolomite were recognized.

- Type 1 dolomite is a syndepositional dolomite. Types 2 and 3 are results of recrystallization of previous dolomites. Saddle dolomite, along with type 4 dolomite fills pores and fractures and is regarded as the final by-product of burial environment.

- Geochemical study of the dolomites of Shotori Formation suggests that $\mathrm{Sr}$ and $\mathrm{Na}$ contents are much more in fine crystal dolomites (type 1 and 2) than in coarse crystal dolomites (type 3 and 4 ) while the amounts of Fe and Mn in coarse crystal dolomites are more than fine crystal dolomites.

- Various dolomitization mechanisms are proposed for various types of dolomites; that is to say, Sabkha model is considered for type 1 dolomite, mixing zone model for type 2 and 3 dolomites and burial model for type 4 and 5 dolomites.

- Since dolomicrites are formed near the surface, their necessary Mg is sourced from seawater, yet, in other dolomites, $\mathrm{Mg}$ is supplied with connate marine waters or basinal brines.

\section{References}

[1] Sibley, D.F. and Gregg, J.M. (1987) Classification of Dolomite Rock Textures. Journal of Sedimentary Research, 57, 967-975.

[2] Lee, Y.I. and Friedman, G.M. (1987) Deep-Burial Dolomitization in the Ordovician Ellenburger Group carbonates, West Texas and southeastern New Mexico. Journal of Sedimentary Research, 57, 544-557.

[3] Amthor, J.E. and Friedman, G.M. (1992) Early- to Late-Diagenetic Dolomitization of Platform Carbonates; Lower Ordovician Ellenburger Group, Permian Basin, West Texas. Journal of Sedimentary Research, 62, 131-144.

[4] Mazzullo, S.J. (1992) Geochemical and Neomorphic Alteration of Dolomite: A Review. Carbonates and Evaporites, 7, 21-37. http://dx.doi.org/10.1007/BF03175390

[5] Mazzullo, S.J. (2000) Organogenic Dolomitization in Peritidal to Deep-Sea Sediments. Journal of Sedimentary Research, 70, 10-23.

http://dx.doi.org/10.1306/2DC408F9-0E47-11D7-8643000102C1865D

[6] Ye, Q. and Mazzullo, S.J. (1993) Dolomitization of Lower Permian Platform Facies, Wichita Formation, North Platform, Midland Basin, Texas. Carbonates and Evaporites, 8, 55-70. http://dx.doi.org/10.1007/BF03175163

[7] Adabi, M.H. (2009) Multistage Dolomitization of Upper Jurassic Mozduran Formation, Kopet-Dagh Basin, N.E. Iran. Carbonates and Evaporites, 24, 16-32.

[8] Adabi, M.H. (2012) Sedimentary Geochemistry. 2nd Edition, Pars Geology Research Center, $504 \mathrm{p}$.

[9] Dickson, J.A.D. (1965) A Modified Staining Technique for Carbonates in Thin Section. Nature, 205, 587.

[10] Dunham, R.J. (1962) Classification of Carbonate Rocks According to Depositional Texture. Vol. 1, American Association of Petroleum Geologists, 108-121. 
[11] Folk, R.L. (1959) Practical Petrographic Classification of Limestones. AAPG Bulletin, 43, 1-38.

[12] Folk, R.L. (1965) Some Aspects of Recrystallization in Ancient Limestones. In: Pray, L.C. and Murray, R.C., Eds., Dolomitization and Limestone Diagenesis, Vol. 13, Society for Sedimentary Geology, Special Publications, 14-48. http://dx.doi.org/10.2110/pec.65.07.0014

[13] Folk, R.L. and Assereto, R. (1974) Giant Aragonite Rays and Baroque White Dolomite in Tepee-Fillings, Triassic of Lombardy, Italy. Society of Economic Paleontologists and Mineralogists, Annual Meeting, San Antonio, 34-35.

[14] Gregg, J.M. and Sibley, D.F. (1984) Epigenetic Dolomitization and the Origin of Xenotopic Dolomite Texture. Journal of Sedimentary Research, 54, 908-931.

[15] Gregg, J.M. and Shelton, K.L. (1990) Dolomitization and Dolomite Neomorphism in the Back Reef Facies of the Bonneterre and Davis Formations (Cambrian), Southeastern Missouri. Journal of Sedimentary Research, 60, 549-562.

[16] Friedman, G.M. (1965) Terminology of Crystallization Textures and Fabrics in Sedimentary Rocks. Journal of Sedimentary Research, 35, 643-655.

[17] Land, L.S. (1985) The Origin of Massive Dolomite: Summary and Suggestion. Journal of Geological Education, 33, 112-125. http://dx.doi.org/10.5408/0022-1368-33.2.112

[18] Adabi, M.H. and Rao, C.P. (1996) Petrographic, Elemental and Isotopic Criteria for the Recognition of Carbonate Mineralogy and Climates during the Jurassic (Examples from Iran and England) (Abstract). 13th Geological Convention, Australia, 6.

[19] Sibley, D.F. (1980) Climatic Control of Dolomitization, Seroe Domi Formation (Pliocene), Bonaire, N.A. In: Zenger, D.H., Dunham, J.B. and Ethington, R.L., Eds., Concepts and Models of Dolomitization, Vol. 28, Society for Sedimentary Geology, Special Publications, 247-258. http://dx.doi.org/10.2110/pec.80.28.0247

[20] Warren, J.K. (2000) Dolomite: Occurrence, Evolution and Economically Important Association. Earth-Science Reviews, 52, 1-81. http://dx.doi.org/10.1016/S0012-8252(00)00022-2

[21] Flügel, E. (2004) Microfacies Analysis of Limestone: Analysis, Interpretation and Application. Springer Verlag, Berlin, $976 \mathrm{p}$.

[22] Radke, B.M. and Mathis, R.L. (1980) On the Formation and Occurrence of Saddle Dolomite. Journal of Sedimentary Research, 50, 1149-1168.

[23] Rahimi, A. and Adabi, M.H. (2010) Dolomitization (Type \& Model) and Their Effect on Reservoir Quality in the Kangan Formation, South Pars Filed. 14th Symposium of the Geological Society of Iran, 14, 2095-2003.

[24] Rahimi, A. and Adabi, M.H. (2011) Determinate Diagenetic Trend and Analysis of Dolomites Based on Petrography and Geochemistry of the Kangan Formation in the South Pars Field, Persian Gulf. 15th Symposium of the Geological Society of Iran, 15, 1005-1016.

[25] Murray, R.C. (1960) Origin of Porosity in Carbonate Rocks. Journal of Sedimentary Research, 30, 59-84. http://dx.doi.org/10.1306/74D709CA-2B21-11D7-8648000102C1865D

[26] Anderson, J.H. (1985) Depositional Facies and Carbonate Diagenesis of the Downslope Reefs in the Nisku Formation (U. Devonian), Central Alberta, Canada. Dissertation, The University of Texas, Austin, 393 p.

[27] Mattes, B.W. and Mountjoy, E.W. (1980) Burial Dolomitization of the Upper Devonian Miette Buildup, Jasper National Park, Alberta. In: Zenger, D.H., Dunham, J.B. and Ethington, R.L., Eds., Concepts and Models of Dolomitization, Vol. 28, Society for Sedimentary Geology, Special Publications, 259-297. http://dx.doi.org/10.2110/pec.80.28.0259

[28] Friedman, G.M. and Sanders, J.E. (1967) Origin and Occurrence of Dolostones. In: Chilin- 
gar, G.V., Bissell, H.J. and Fairbridge, R.W., Eds., Carbonate Rocks, Origin, Occurrence, and Classification, Elsevier, Amsterdam, 267-348.

[29] Zenger, D.H., Dunham, J.B. and Ethington, R.L. (1980) Concepts and Models of Dolomitization. Vol. 28, Society for Sedimentary Geology, Special Publications, 320 p. http://dx.doi.org/10.2110/pec.80.28

[30] Morrow, D.W. (1982) Diagenesis II. Dolomite-Part II: Dolomitization Models and Ancient Dolostones. Geoscience Canada, 9, 95-107.

[31] Land, L.S. (1983) Dolomitization. AAPG Education Course Note Series 24, 1-20.

[32] Machel, H.G. and Mountjoy, E.W. (1986) Chemistry and Environments of Dolomitization-A Reappraisal. Earth-Science Reviews, 23, 175-222. http://dx.doi.org/10.1016/0012-8252(86)90017-6

[33] Hardie, L. (1987) Dolomitization: A Critical View of Some Current Views. Journal of Sedimentary Research, 57, 166-183. http://dx.doi.org/10.1306/212F8AD5-2B24-11D7-8648000102C1865D

[34] Shukla, V. and Baker, P.A., Eds. (1988) Sedimentology and Geochemistry of Dolostones. Vol. 43, Society for Sedimentary Geology, Special Publications, 266.

[35] Veizer, J. (1983) Trace Tlements and Stable Isotopes in Sedimentary Carbonates. In: Reeder, R.J., Ed., Carbonates: Mineralogy and Chemistry, Reviews in Mineralogy, Vol. 11, Mineralogical Society of Amer, 265-299.

[36] Humphrey, J.D. (1988) Late Pleistocene Mixing Zone Dolomitization, South-Eastern Barbados, West Indies. Sedimentology, 35, 327-348. http://dx.doi.org/10.1111/j.1365-3091.1988.tb00951.x

[37] Rao, C.P. (1996) Modern Carbonates, Tropical, Temperate, Poolar: Introduction to Sedimentology and Geochemistry. 206 p.

[38] Land, L.S. (1980) The Isotopic and Trace Element Geochemistry of Dolomite: The State of the Art. In: Zenger, D.H., Dunham, J.B. and Ethington, R.L., Eds., Concepts and Models of Dolomitization, Vol. 28, Society for Sedimentary Geology, Special Publications, 87-110. http://dx.doi.org/10.2110/pec.80.28.0087

[39] Veizer, J. (1978) Secular Variations in the Composition of Sedimentary Carbonate Rocks, II. Fe, Mn, Ca, Mg, Si and Minor Constituents. Precambrian Research, 6, 381-413. http://dx.doi.org/10.1016/0301-9268(78)90024-4

[40] Vahrenkamp, V.C. and Swart, P.K. (1990) New Distribution Coefficient for the Incorporation of Strontium into Dolomite and Its Implications for the Formation of Ancient Dolomites. Geology, 18, 387-391. http://dx.doi.org/10.1130/0091-7613(1990)018<0387:NDCFTI >2.3.CO;2

[41] Land, L.S. and Hoops, G.H. (1973) Sodium in Carbonate Sediments and Rocks: A Possible index to the Salinity of Diagenetic Solutions. Journal of Sedimentary Research, 43, 614-617.

[42] Sass, E. and Bein, A. (1988) Dolomites and Salinity: A Comparative Geochemical Study. In: Shukla, V. and Baker, P.A., Eds., Sedimentology and Geochemistry of Dolostones, Vol. 43, Society for Sedimentary Geology, Special Publications, 223-233. http://dx.doi.org/10.2110/pec.88.43.0223

[43] Tucker, M.E. and Wright, V.P. (1990) Carbonate Sedimentology. Blackwell, Oxford, 482 p. http://dx.doi.org/10.1002/9781444314175

[44] Pingitore, N.E. (1978) The Behaviour of $\mathrm{Zn}^{2+}$ and $\mathrm{Mn}^{2+}$ during Carbonate Diagenesis: Theory and Applications. Journal of Sedimentary Research, 48, 799-814.

[45] Land, L.S. (1986) Environments of Limestone and Dolomite Diagenesis: Some Geochemical 
Considerations. Colorado School of Mines Quarterly, 81, 26-41.

[46] Warren, J.K. (2006) Evaporites: Sediments, Resources and Hydrocarbons. Springer, Berlin, 1036 p. http://dx.doi.org/10.1007/3-540-32344-9

[47] Badiozamani, K. (1973) The Dorag Dolomitization Model, Application to the Middle Ordovician of Wisconsin. Journal of Sedimentary Research, 43, 965-984.

[48] Hanshaw, B.B., Back, W.E. and Deike, R.G. (1971) A Geochemical Hypothesis for Dolomitization by Groundwater. Economic Geology, 66, 710-724.

http://dx.doi.org/10.2113/gsecongeo.66.5.710

[49] Moore, C.H. (1989) Carbonate Diagenesis and Porosity. In: Developments in Sedimentology, Vol. 46, Amsterdam, Elsevier, 46-338.

Submit or recommend next manuscript to SCIRP and we will provide best service for you:

Accepting pre-submission inquiries through Email, Facebook, LinkedIn, Twitter, etc. A wide selection of journals (inclusive of 9 subjects, more than 200 journals)

Providing 24-hour high-quality service

User-friendly online submission system

Fair and swift peer-review system

Efficient typesetting and proofreading procedure

Display of the result of downloads and visits, as well as the number of cited articles

Maximum dissemination of your research work

Submit your manuscript at: http://papersubmission.scirp.org/

Or contact ojg@scirp.org 